Security in the Society of Control: The Politics and Practices of Securing Urban Spaces

\title{
Journal Article
}

Author(s):

Hagmann, Jonas

Publication date:

2017-12

Permanent link:

https://doi.org/10.3929/ethz-b-000223128

Rights / license:

In Copyright - Non-Commercial Use Permitted

Originally published in:

International Political Sociology 11(4), https://doi.org/10.1093/ips/olx020 


\title{
Security in the Society of Control: The Politics and Practices of Securing Urban Spaces
}

\author{
JONAS HagmanN \\ ETH Zürich
}

\begin{abstract}
In the view of some Deleuzian scholars, societal steering evolved from analogue disciplining of static enclosures into network-centric, privatized, digital, and global control. This article re-engages the control thesis from a decidedly empirical security studies perspective. In the age of globalization and urbanization, technological innovation and liberal policy ideals, how are security apparatuses reorganized, and in what relations do they stand to local societal and political orders? The article argues that the Deleuzian framework indeed proposes an impressively rich, integrative, and topical research agenda-but also that its security studies applications can benefit from further development. With a view to vindicating its analytical potential, the article first systematizes the control thesis. It then employs a spatial and empirical heuristic to inquire into the securing of three distinct urban spaces-a site of mobility, a public square, and a place of mass commerce-and to illustrate the actual (re-)configuration of contemporary security management. Forgoing articulation of universalisms about societal steering, the article makes the case for more nuanced engagements with security ensembles, their technological evolution, and their relations with democratic ideals, globalization, and de-territorialization, both in and beyond Western polities.
\end{abstract}

In the view of some scholars, the governing logics of modern societies recently witnessed a veritable paradigm shift, as the Foucaultian "society of discipline" progressed into the now dominant Deleuzian "society of control." With this transition, new qualities of security management emerged: In the society of control, human behavior is monitored much more comprehensively than before (Deleuze 1992). Societal policing is spatially unconfined, generalized, and network-centric and relies strongly on high-tech instruments and private security actors (Hardt 1998). As a normalizing system imposing itself ever more forcefully on the social and personal body, this new mode of societal steering is seen to challenge democratic ideals ever more strongly. Contemporary security dispositives transcend enclosures and borders and operate by digital means and capitalist interests. They force themselves onto individuals, screen and exclude some but not others, and are oriented to political finalities little debated-and consequently, the need is identified to question, resist, or even reject said new control systems.

By alluding to the Deleuzian society of control, scholars propose new ideas of what became of the disciplinary society described by Foucault, and in doing so they contribute stimulating elements to security studies. Analytically, the Deleuzian concept allows us to approach security arrangements as comprehensive and fluid 
ensembles of diverse modern instruments, be it the built environment, digital surveillance technologies, human agents, legal codes, or social norms. It helps question their variegated origins and finalities, globalization and deterritorialization, the types of power on which they draw, the public-private partnerships through which they operate, and their praxeological effects on democratic politics broadly conceived. Empirically, the control thesis empowers a decidedly genealogical research agenda: How security dispositives are (re-)assembled, where they stand in relation to local societal and political orders, and how their configurations evolve over time and space, are questions that can be answered by contextualized empirical enquiry.

Yet, a closer look at the literature suggests that critical IR in general, but also critical security studies more narrowly, has not engaged the control framework very systematically thus far. In critical IR, Deleuze's work is mainly appropriated through concepts such as rhizome (Reid 2014), assemblages (Muller 2008; Meiches 2015), or nomadic science (Molloy 2010), that is, a political theory perspective (Lenco 2014; Lundborg and Vaughan-Williams 2015). Also, given Deleuze's emphasis on new forms of capitalism, considerable empirical attention is given to the political economy side of his work, as opposed to its security dimension (e.g., Hardt and Negri 2000; Bailey 2010; Vlcek 2010). Critical security studies, by contrast, often continue to draw on Foucault and thus the comparatively older notion of the analogue and spatially confined society of discipline to engage contemporary security practices (e.g., Salter 2007; Dillon and Lobo-Guerrero 2008). Deleuze has been brought into the subfield through the philosophical notions of affect and becoming and, notably, his collaboration with Guattari (e.g., Adey 2008; Lundborg 2016) -but the control framework itself remains surprisingly rarely invoked and, in the few cases it is, much attention is directed to CCTV surveillance, digital databases and private security producers as elements of contemporary security.

This is not to downplay the productivity of existing IR approaches to Deleuze-to the contrary. The notions of assemblages and nomadic theory, for instance, generate new insights into the combined material and immaterial nature of dispositives (Rose 2000), corporatist policy partnerships (Abrahamsen and Williams 2010), and IR theorizing proper (Gammon and Reid 2010; Molloy 2010). In security quarters, the mobilization of Deleuzian contributions, other than his control thesis, helps problematize security-minded activations of human predispositions (Adey 2008) or offers alternative takes on the performativity of uncertainty (Lundborg 2016). For a full account of how security dispositives are rearranged today, however, current appropriations of the control framework appear surprisingly limited. Whereas critical IR omits the security aspect of Deleuze's control concept, thereby downplaying its crucial focus on new security assemblages, critical security studies either disregard Deleuze, ignore his control thesis, or reduce the latter to a mere question of databases, cameras, and private actors. With this, much of the empirical breadth and complexity of contemporary security management is passed over, and holistic analyses of current security practices are foregone.

The ambition of this article is to address this gap and to reengage Deleuze's control thesis from a decidedly empirical, security studies perspective. In the society of control-that is, the current age of globalization and urbanization, technological innovation, and liberal policy ideals-how are security apparatuses reorganized? On what actors and technologies do they rely, and how is participatory policymaking reconfigured with their evolution? By raising these questions, the article pursues two goals. At the analytical level, it seeks to position the control framework, whose roots reach deeply into the humanities, as a useful and stimulating security studies framework. At the empirical level, it seeks to promote a more differentiated understanding of security dispositives, for fieldwork suggests that these must not be reduced so quickly to the features foregrounded by Deleuzian control scholarship. Combining these two elements, the article's overarching aim is thus to 
present contemporary security dispositives as valuable IR research objects but also as objects that demand considerably more nuanced, interdisciplinary, and empirical engagement.

The article contains three sections. The first section presents and systematizes the society of control from a security perspective. It details the existing literature's pioneering contributions but also challenges its applications of the control thesis as surprisingly selective overall and thus argues for a more holistic inquiry into contemporary security management. The second section draws on fieldwork to assess the (re-)configuration of security dispositives in and around three distinct urban sites in Switzerland. Contrasting the empirical findings with the control literature, it shows that significant parts of Deleuzian control scholarship do indeed fail to account for the full diversity and complexity of current security apparatuses and that a number of its claims are overdrawn. The conclusion draws on the empirical findings to argue for a more empirical, contextualized, and comparative analysis of security dispositives, their technological evolution, globalization, and deterritorialization.

\section{Security in the Society of Control}

The notion of the society of control was put forward by philosopher Gilles Deleuze in his 1992 Postscript on Societies of Control, one of his "shortest but most popular and inspirational texts" (Cheng 2008, 1). In this manifesto, Deleuze argued that societal steering had evolved into new forms by the late twentieth century. Expanding on Michel Foucault, who showed how government rationalities had earlier evolved from sovereign to disciplinary forms of rule (Foucault 1977, 1991) and how life thus became a matter of moving from one normalizing institution to the next-the family, school, barracks, factory, and occasional stays in hospital or prison-Deleuze stressed the debordering of these enclosures. With capitalism's self-reinvention as a global service industry, but notably also given technological advances and following a generalized "crisis of the institutions," he argued, life transcended institutional walls. With it, apparatuses of security-assemblages of actors and instruments destined for monitoring the population and enforcing aims and standards among it (Foucault 2004; Bigo 2005)_adapted, becoming more modular, far-reaching, and intrusive.

Deleuze's diagnosis received significant attention in the humanities (cf. Massumi 2002; Virilio 2012; Lenco 2014), and, as already mentioned, the argument eventually also showed up in different forms in (critical) IR and its security studies subfield. Yet, scholars sympathetic to Deleuze's work also recognized the manifesto as "rather metaphor-like" (Rose 1999) and "little tangible" (Hardt 1998), its productive description of the zeitgeist notwithstanding. But although these scholars requested further specifications, a comprehensive systematization of the control society and, especially, its new security apparatus must still be deduced from the literatures that followed the Postscript. According to these, modern security dispositives are characterized by a distinct internal (re-)composition, evolving relations with democratic life writ large, expanding reach, and global presence, as well as implicit and possible political agendas and/or drivers.

First, in terms of configuration, security management today is held to rely on considerably more complex combinations of actors and instruments. In the society of control, according to a widely shared view in the literature following the Postscript, actor-types multiplied, and experts of all sorts assumed normalizing functions, from police agents to health specialists, social workers and so on (Rose 2000; Koskela 2003; Deleuze 2006). What is more, the new constellation of security actors shifted from public to private operators. Although some authors consider this shift a gradual process, with hybrid modes emerging (Haggerty and Ericsson 2000), its direction away from the public and towards the private seems undisputed, and many 
writers suggest a complete transition to the latter (e.g., Hallsworth and Lea 2011; Tiessen 2011; Wichum 2013).

The new security apparatuses also draw on more sophisticated instrumentssurveillance technologies such as databases, scanners, digital keys, and CCTV cameras in particular (Tiessen 2011). It is these technologies that make the city transparent (Koskela 2003), create an electronically augmented super-panopticon (Lyon 2001), and allow ever more proximate societal control (Deleuze 1992; Rose 2000). Bringing new actors and instruments together, the dispositives become impressively flexible overall. Unlike the static disciplinary dispositives, control ensembles "modulate endlessly" (Deleuze 1992; Tiessen 2011). They "design security into flows" (Rose 2000, 325) and continuously adapt with them. Current security dispositives respond immediately (Virilio 2012), or at least from one moment to the next (Deleuze 1992), to changes in the social bodies that they monitor and normalize.

Second, the new apparatuses encroach on democratic politics in different ways. Already, there is a general sense in Deleuzian control scholarship that societies are governed more intimately through notions of security today (Zedner 2009; Valverde 2010) and that this trend is difficult to problematize, since security defies established justification requirements (Zedner 2003). What is more, the new dispositives are seen to manage the population from a distance and as systems from which individuals can no longer escape: policemen are barely in contact with ordinary people any longer (Koskela 2000); security interventions rely on distant statistics (Deleuze 1992); and new security technologies-CCTV cameras especially-are instruments that operate in a gazing, and thus one-way, direction, "looking at the populace like god-like observers" (Koskela 2003, 298). This "removed" security apparatus is so comprehensive that its agents and instruments can no longer be avoided (Hardt 1998; Koskela 2003). In the control society "one might run, but there is no longer a place to hide" (Cheng 2008, 24). People are controlled, categorized, and normalized whether they want it or not (Koskela 2003), for "control is continuous and without limit" (Deleuze 1992, 6).

But control arrangements also impair democratic life in other ways. There is an understanding among Deleuzian scholars that the new dispositives focus intimately on designated problem groups, even if they monitor everyone at the operational level. Factually, this means that some parts of society are regularized more strongly than others, for "every young person is potentially a thug or a criminal, and every Muslim potentially a terrorist" (Newman 2009, 106). This modus operandi also impairs inclusive politics, for it rests on and re-instantiates an understanding of some being different, if not detached from society-a divisive effect that is then deepened by the institutionalization of the chosen measures (Virilio 2012, 58-59). ${ }^{1}$ Taken together, it is following such argumentation that control scholars posit the new society as a "system of domination" (Deleuze 1992). In the view of many, the society of control amounts to a new form of authoritarianism, the "counterpart of freedom" or even "soft fascism" (Hardt 1998; Rose 2000; Wichum 2013). It depicts democracies that degenerated into "totalitarian police states" (Newman 2009) or "security states" operating in permanent states of exception (Hallsworth and Lea 2011). Following on from this understanding, control is often likened to an apparatus in the literature. As a particular linguistic transposition of the French term "dispositive," this notion stresses the automated, imposed, and "strangling" aspects of contemporary security ensembles (Bussolini 2010).

Third, the new security ensembles are understood to develop increasingly global operational reach and presence. In the society without walls, "geography has ended" (Lacy 2008; Virilio 2012). As an intensification, generalization, and perfection of the Foucaultian disciplinary society of the nineteenth and twentieth centuries,

\footnotetext{
${ }^{1}$ On the reproduction of fear through security ensembles, and the operational selectivity of modern panopticons, see also Bigo (2001, 2005).
} 
control dispositives reach beyond enclosures (Haggerty and Ericsson 2000; Lyon 2001), turning citizens into "inmates outside the prison" (Hardt and Negri 2000). Koskela (2003, 294-95), for example, maintains that the panopticon is now present "everywhere in every major city." Most writers working with Deleuze's control concept, however, identify an even wider reach on the part of the new security arrangements. In their view, the age of control produced one global control system, not merely integrated local or national security apparatuses. In contrast to Deleuze's own emphasis on the plurality of security dispositives, then, a sizeable number of authors refer to a singular and planetary control system (Hardt and Negri 2000) - a point well illustrated by Hardt's (1998) reformulation of Deleuze's essay title from Societies of Control to The Global Society of Control.

Fourth and finally, the control society is associated with implicit and potential political projects and/or drivers. There is a widespread understanding that the perfection of control is fueled by neoliberal politics, the privatization of services, technological advances, and alarmist threat discourses-fear of terrorism especially (Munro 2002; Coaffee, O'Hare and Hawkesworth 2009). These elements stimulate an expansion of security dispositives that is uncontrolled and organized at the same time. Security instruments are seen growing horizontally in rhizomatic ways and with little strategic coherence (Rose 2000, 321-322), yet the advent of the control system is nonetheless deemed systematic and thus top-down overall (Coleman and Agnew 2007). ${ }^{2}$ And indeed, capitalism is recurrently identified as the one authority that, albeit rarely subjected to popular approval, orchestrates the control society and its apparatuses of security, which is why they are often associated with an implicit neoliberal agenda (Reid 2014). ${ }^{3}$

This political agenda is not the only one possible, of course, and following diagnoses of security dispositives encroaching on democratic politics, it is also not deemed desirable. That is to say that the comprehensiveness, exclusionary practices, totalizing aspirations, and implicit neoliberal inspirations of current security dispositives motivate scholars to critically engage the new control ensembles. Indeed, calls to problematize, resist, or even reject the new control systems abound in the literature (Lacy 2008). And although the components of such strategies or tactics are rarely specified in the scholarly literature (as opposed to activist writings elsewhere; see The Invisible Committee 2009), it is clear from the literature that followed the Postscript that new security dispositives should be met with resistant activities of some sort (Newman 2009; Deseriis 2011; Lundborg 2016).

Taken together, it seems no exaggeration to state that with these analytical components, the Deleuzian control thesis advances an impressively rich, integrative, and topical research agenda. Even if the postulation of a neat paradigm shift from "discipline" to "control" seems overstated (Poster 2009) ${ }^{4}$ - the control thesis directs attention to evolving varieties of functionally diverse security actors, the continuing recomposition of material and immaterial security assemblages, the multiple and evolving linkages between security and democratic politics writ large, and novel deterritorialization processes, as well as normative dimensions inherent in

\footnotetext{
${ }^{2}$ It goes without saying that the postulation of a rhizomatic, yet systematic, expansion of security dispositives makes it difficult to identify the precise drivers of the latter process. Deseriis (2011) considers this challenge, to whose clarification Deleuzian scholarship contributed little, to reflect a deeper ambivalence in Marxist theorizing, namely the core question of whether capitalism organizes itself (a rhizomatic perspective set out in Marx's Grundrisse) or whether it is orchestrated by a "capitalist general" (a systemic reading suggested in Das Kapital).

${ }^{3}$ Seemingly, it is also the globalized nature of capitalism that motivates Deleuzian scholars to conclude a global control system-thus confusing characteristics of a driver of control with the nature of security dispositives' own operation.

${ }^{4}$ Since some "Deleuzian elements" had been anticipated or called for by Foucault already, such as the necessity to overcome institution-centric analyses of societal steering (Foucault 2004, 116-118, on the "crisis of disciplinary societies"; also Foucault 1978). Overall, and with the exception of Deleuze's more explicit concerns with digitalism, privatization, and society's ability to influence security dispositives perhaps, it thus seems useful to conceive of "control" more as an intensification and spatial expansion of the security arrangements set out by Foucault. Control is not a fundamental rejection of discipline, even if it is defined in relation to the latter.
} 
contemporary security management. Doing so, the Deleuzian framework advances a fairly integrative "critical" perspective on the interrelations between security dispositives, democratic politics, and emancipatory practices-indeed, more holistic maybe than the division of academic labor between Foucaultian/Bourdieuan, Arendtian, and Marxist approaches to security research ("Paris, Copenhagen, Aberystwyth") allows.

As important, the control framework allows a variety of highly current empirical observations to be engaged: Deleuzian control studies can address concerns about societies becoming governed ever more intimately in the name of security and about security dispositives becoming more intrusive and ubiquitous (Valverde 2010). It can situate the evolution of such logics and dispositives in broader contemporary processes such as technological innovation (evolving "infrastructural powers"), globalization (the reconfiguration of enclosures and borders), and urbanization (the intensification of the Foucaultian problem of population, or "coexistence" ${ }^{5}$; and it can examine these through interscalar lenses (Delaney and Leitner 1997; Brenner 1999), addressing the variegated ways in which international security narratives become localized and local security dispositives transnationalized. Seen this way, the control thesis empowers highly topical and comprehensive accounts of the interplay between security ensembles, democratic politics, and normative choices and allows decidedly empirical "genealogies of governmentality" (Bevir 2010; Joseph 2010) across clinical levels of analysis.

This said, a look at the contributions made thus far suggests that the controloriented literature has, in its applications to security, not exploited this potential very systematically. While the literature has offered sophisticated case studies and played a pioneering role in popularizing the control framework in the first place, some of its analyses appear surprisingly incomplete and little differentiated, if not outright overdrawn. Whether security dispositives indeed came to draw so strongly on private agents, for instance, clearly deserves further enquiry (Coleman and Agnew 2007), and so does their alleged reliance on digital instruments and pronounced flexibility (Blomley 2007; Bonelli and Ragazzi 2014; Meiches 2015). Whether the new security ensembles might reformulate democratic politics (Loader and Walker 2007), as opposed to closing it down, has not been answered conclusively, seemingly because the authoritarian penchant of security is considered wellproven among control scholars. The purported presence of global control warrants further analysis-not only because of the mere grandiosity of this statement but also given the literature's strong reliance on insights from the United Kingdom and North America (e.g., Newman 2009; Vlcek 2010; Hallsworth and Lea 2011), that is, its narrow empirical base. The postulated linearity of the described shifts is counterintuitive, considering the genealogical method and ethos on which Deleuzian work draws, and the emphasis on terrorism as the most immediate justification for new control arrangements points to an exceedingly rapid reduction of security affairs to $9 / 11$ discourses. Whether resistant practices are still to come, finally, is also a point to explore further, for most security studies applications of Deleuze's control argument derive such need from the technical intrusiveness of new security instruments, not from an empirically verified absence of opposition to control ensembles (Merlingen 2006).

Considering these limitations, it is important to challenge the Deleuzian control literature for its selectivity, its merits notwithstanding (Valverde 2010). Instead of providing holistic and contextualized accounts of contemporary security management and its variation across time and space, as its analytical set-up would permit (Goldstein 2010), its empirical contributions still emphasize some actors, instruments, and processes and ignore others. Today, such partial engagement with evolving security assemblages is little conducive to fostering a grounded understanding

${ }^{5}$ These macrotrends are also found in Foucault (1991, 98, 335ff), who simply calls them "general processes." 
of the complex politics and practices of contemporary security management. But if acknowledged, it can also serve as stimulus for further research into security dispositives and their relations with democratic politics, broadly defined. It is according to this latter perspective-and hence also with a view to expanding the existing literature and to vindicating the analytical and empirical potential of the Deleuzian control framework set out earlier-that the following section adopts a decidedly empirical perspective on the evolution of contemporary security management in urban spaces. ${ }^{6}$

\section{The Politics and Practices of Securing Urban Spaces}

A focus on urban spaces serves as both empirical and "critical" research strategy (Aradau and Huysmans 2014). Instead of advancing a dedicated focus on new elements such as high-tech instruments and private actors-and then concluding to an era of digital surveillance and capitalist interests-a spatial (or "ecological" [Bennett 2004]) heuristic directs attention to wider milieus in which human activities occur and become regularized (Foucault 2004, 20-23). Analytically, such a perspective chimes well with Deleuze's interests in contemporary processes such as the debordering of enclosures (globalization) and the intensification of the "problem of coexistence" (urbanization). Empirically, it empowers more holistic accounts of security apparatuses, for the notion of the urban space directs research to physical locations as well as their wider surroundings (Castels 1988); to technologies of different sorts (Amicelle, Aradau and Jeandesboz 2015) but also factors such as the built environment, human actors, legal codes, and social norms (Lefebvre 1968; Valverde 2010; Muller and al. 2016); and to configurations of local security apparatuses and, through the notion of the discursive space, their wider deliberative/political implications (Goodsell 2003).

The focus on urban spaces, then, respects the central interests of Deleuze's analytics but also empowers more open-ended assessments of security ensembles. It allows foregrounding what more, or what else, can be shown at the hands of Deleuze's argument, and with this it permits a reconsideration of established understandings of what control is or can be. ${ }^{7}$ And indeed, a (deliberately) deep empirical investigation into the politics and practices of securing three functionally different urban spaces in Switzerland-a highly urbanized polity ${ }^{8}$ whose pronouncedly liberal regulatory frameworks, material wealth and ability to develop or acquire the most sophisticated security instruments, and elaborate democratic decision-making mechanisms offer a most likely case for the purported control arguments to be observed-suggests that contemporary security management is considerably richer, more complex, and diverse than that currently proposed by Deleuzian control scholarship. As these case studies show, this is also because novel control instruments do not render old ones redundant, and security dispositives depend strongly on the distinct social, political, and material space in which they operate.

A comprehensive qualitative research effort serves to substantiate these claims. Following an anthropological understanding, according to which societies are constituted by ideal-typical "societal infrastructures" (Larkin 2013), sites of mobility, public life, and economics in particular, the subsequent empirical narrative traces the recent (last fifteen years) evolution of security ensembles at and around Zürich main station, Bundesplatz Bern, and St. Jakob Park, Basel. Its development is based on extensive literature work, site visits, and structured interviews with all

\footnotetext{
${ }^{6}$ The urban focus doesn't deny the importance of rural control systems, but echoes the circumstance that the majority of the world's inhabitants now live in cities (Abrahamsen, Hubert and Williams 2009), and that cities have become particularly important instances of security politics (Coward 2009).

${ }^{7}$ On the reflexive potential of deeply empirical security studies enquiry see also Johnson (2014).

${ }^{8}$ In 2017 more than $80 \%$ of the Swiss population lives in urban settlements.
} 


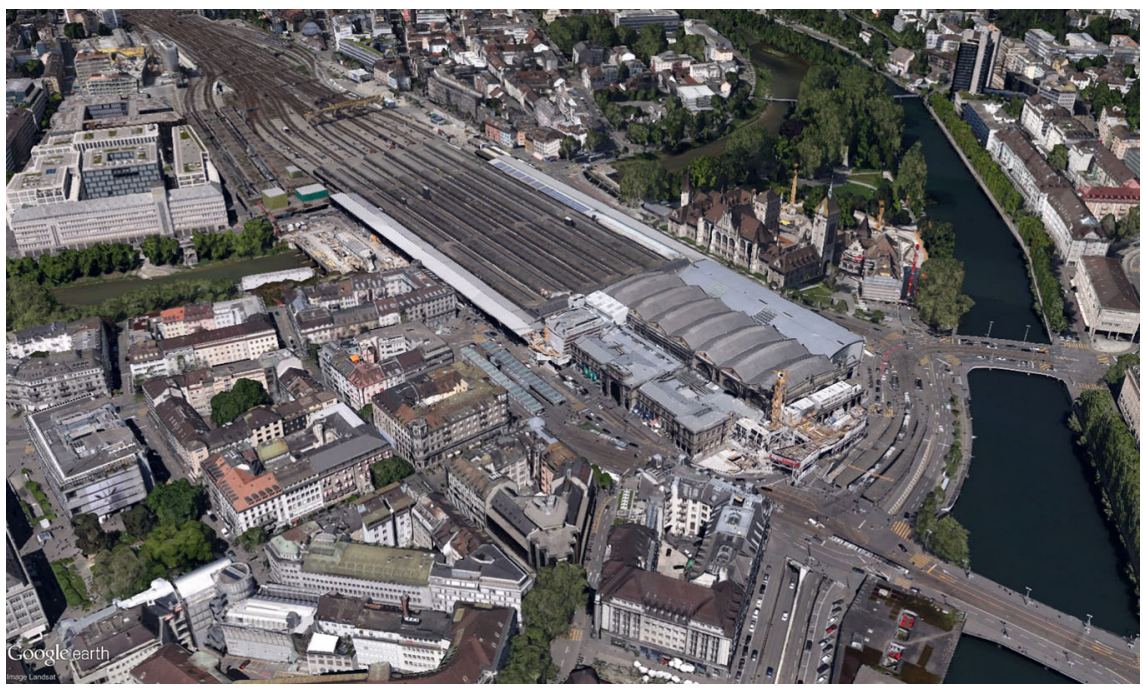

Figure 1. Zürich Hauptbahnhof.

those actors identified by documents, visits, and chain-referrals as central to the handling of security in the selected spaces. These include site managers (Wincasa, FC Basel, SBB Infrastructure Division), architects (Lee \& Mundwiler, Herzog \& de Meuron, Aebi \& Vincent, Dürig), city police (Zürich), cantonal police (Basel, Bern, Zürich), Transport Police, the Federal Security Service, public prosecutors (BaselStadt, Bern-Mittelland, Zürich-Sihl), semi-public security entities (Securitrans, SBB Public Security Division), public transport (Basler Verkehrsbetriebe, Bernmobil, Zürcher Verkehrsverbund, SBB Rail), public administration (Sportamt Basel), private security (Basel United, PASS AG), professional associations (FIFA, UEFA, International Union of Railways), social workers (Fanarbeit Schweiz), civil society groups (IG Bern-City, Pro Bahn), commercial associations (Verein Bern-Märit), and individual site users (travelers, passengers, football fans, consumers, etc.).

\section{Securing a Site of Mobility}

The security dispositive centering on Switzerland's premier site of mobility, Hauptbahnhof Zürich, offers a first instructive case of control practices' multifaceted manifestation. Zürich main station is a multilevel ensemble of one surface and three subterranean train stations. With its platforms for trams, buses, taxis, and boats, it is a hub for local, regional, national, and international travel, handling 450,000 train passengers each day and connecting to destinations as far away as Hamburg, Paris, and Belgrade. The Hauptbahnhof is also a passageway between boroughs, a workplace for two thousand individuals, and a shopping district open 365 days a year, with over 180 stores and services (including a clinic and police station) and fifty restaurants or takeaways. Its main hall, stripped of tracks in 1930, is one of the largest covered spaces in Switzerland and regularly hosts concerts, markets, fairs, and manifestations (SBB 2016, cf. Figure $1^{9}$ ).

First, the dispositive's reconfiguration partly supports existing scholarly arguments, for security actors have multiplied in recent years. Adding to Cantonal and Zürich City Police (present with uniformed and plain-clothed agents), the

\footnotetext{
${ }^{9}$ The article's three figures were produced in early 2016 with Google Earth Pro. This software gives good indications of the urban sites' spatial arrangements. But it also strips the strongly frequented spaces of (most) humans and vehicles, thus giving them a certain sanitized feel.
} 
Federal Railways (Schweizerische Bundesbahnen, or SBB) started relying strongly on the Transport Police, a new corps founded in 2001 with a view to patrolling trains across Switzerland (since 2002, international trains have been controlled by the Border Guards). Within the station, the SBB began deploying guards through Securitrans, a joint venture of SBB and private company Securitas. In exceptional cases, such as disruptions of rail networks, it now sends out clerks and reserve train drivers as auxiliary security assistants. The city began employing a new type of "robust" social worker (the $S I P$ ) in and around the Hauptbahnhof in the early 2000s, with a mandate to foster dialogue with marginal groups and youngsters.

The purported shift to private actors, however, is less evident. While Securitrans employees multiplied, the public railways retained majority oversight of these guards, and their increase in numbers probably speaks more to the dramatic increase in train traffic (and multiple Bahnhof expansions) than to a qualitative tightening of control. ${ }^{10}$ Indeed, the only pure private security actors at the main station are deployed by Migros, an all-purpose retailer who declined to hire Securitrans, and event organizers, who must provide their own security when renting the hall. Given this, the trend towards private security seems undramatic. On the one hand, private actors are nothing new, for the SBB has been hiring private guards since the early twentieth century. On the other, many around the main station deem private actors unsuitable for safeguarding open spaces and concentrations of people, which is why they are not used more widely, and fundamental control functions remain with the police. $^{11}$

A similarly ambivalent situation applies to instruments. High-tech tools were progressively installed. After the inauguration of the first underground platforms in 1991, cameras were mounted at Hauptbahnhof (and since 2004 on trains) in expanding quantity and quality (on-site cameras can be steered remotely today, but none has face recognition). A nationwide digital communication network for first responders was created in 2003 and built into the station. For the last ten years, cameras, sensors, and communication among security personnel have been managed from an on-site control room. ${ }^{12}$ SBB developed a database for the roughly one thousand individuals it barred from the premises, and Cantonal Police developed an app with which to coordinate patrols. When screening individuals, policemen query national databases AFIS (fingerprints, automated 1984), RIPOL (criminal investigations, 1987-), ZEMIS (foreigners, digitalized since 2008), and HOOGAN (sanctioned hooligans, 2007-) and the European Schengen (2008-) and Visa Information System (2011-).

But there is also much more expansive use of low-tech. Walls and floors (lighter colors, wear-proof fabric), stairs, walkways (improved signaling, reduction of edges, dark corners, and dead-ends), lines of sight, waste disposal, and lighting were systematically redesigned to tackle subjective insecurity and enhance social control. ATMs and ticket machines were repositioned in ways to diminish the risk of theft, shops were instructed to not let merchandise impede lines of sight, and benches were reworked to reduce loitering. The entire perimeter can now be closed overnight, a practice still common on weekdays.

Nuances also apply to the legal domain. Federal, cantonal, and communal norms ranging from homeland security to public transport, penal and procedural law, explosives, residence permit, property rights, and house rules can be used for prevention, screening, and repression purposes, such as identification, Eingrenzung

\footnotetext{
${ }^{10}$ The shift to Transport Police and Securitrans also reflects a reconceptualization of train conductor authority. Whereas conductors historically enjoyed powers to police trains, passengers and stations, they became construed as mere service or information personnel by the mid-1990s.

${ }^{11}$ Private actors are, however, considered effective in guarding entrances of closed buildings elsewhere, for instance, good doormen or bouncers.

${ }^{12}$ It also surveys the station's one movement sensor, installed in the main hall every December to sound an alarm if someone climbs the Christmas tree.
} 
(prohibition to leave designated spaces), Wegweisung (stay-away orders), Meldepflicht (orders to report, for example, for convicted hooligans during games), fines, or arrests. These provisions' reach and applications evolved. Fines became costlier, reprehensions delivered faster, and youngsters and football-fans turned into objects of distinct regulation, thus confirming the control thesis' argument on normative targeting. Whether the legal realm turned "totalitarian" in this process remains a difficult question. Procedurally, any alleged perpetrator may invoke appeal tools from administrative objection to settlement by cantonal, federal, and European tribunals. Furthermore, some provisions are poorly enforced or ineffective in practice-such as the banning of offenders from SBB premises, a tool overridden by the railways' obligation to transport any ticket holder.

Taking actors and instruments together, the dispositive shows new traits of flexibility. Police stations are open longer hours and patrols also deployed in the evenings. SIP accompanies youngsters from Hauptbahnhof to party and drinking places elsewhere in the city, and SBB deploys auxiliary assistants on short notice. Major parts of the dispositive, however, follow fairly rigid operational logics. Most high- and lowtech instruments function in predefined, not very flexible or rapidly adaptable ways once installed. Guards and patrols strongly rely on standardized operating procedures, which are merely adjusted to known reoccurring events such as rush-hours, weekends, seasons, ${ }^{13}$ football games, city festivals, or events at the main hall (security for the latter is cleared two months ahead of time). In practice, only parts of the dispositive are thus adapting as quickly as argued.

Second, the dispositive's "anti-democratic" traits are nuanced. Already, control is less sophisticated and comprehensive than argued-patrols are not everywhere all the time. Camouflage remains possible around Hauptbahnhof, and CCTV footage is almost always used for ex post investigations only. ${ }^{14}$ Security personnel are trained for responsive communication with civilians and sent on patrol for this very purpose. Guarding and patrolling draws strongly on experiential knowledge, not sterile statistics, and agents' ideas of unwarranted behavior are diverse and dynamic. Site managers and wards differentiated between travelers and (self-reliant) commuters in the past, and added shoppers, youngsters and the marginalized as new container concepts. Policemen mostly consider the unruly punks and macho "Balkan boys" passé, East European and Latin American organized groups a persistent challenge, and North African unskilled petty thieves the most recent problem. Important subjectivation practices thus exist at Hauptbahnhof. But they are incongruent, evolving, and do not create one neatly straightjacketed "other."

With this, Hauptbahnhof security is less totalizing in practice than in scholarly writing. Its enactment features sizable elements of imposed control but is less comprehensive, removed, or rigid than claimed. Crucially, the apparatus contains numerous old and new, on- and off-site channels for feedback, complaint, deliberation, and collective decision-making. Securitrans guards and policemen can be talked to at counters, by phone, hotline, email, webform, and apps. SBB quantitatively surveys passengers' security perceptions, hires mystery testers to retrace on-site experiences, and consults with neighborhood associations and ProBahn, an internationally connected civil society group defending passenger rights since 1999. Most important, perhaps, a wealth of local, cantonal, and national media outlets and lawmaking and election mechanisms (including referenda and initiatives rights) are regularly drawn on by politicians and civil society groups to problematize security practices.

\footnotetext{
${ }^{13}$ Station users convene at warmer underground levels in winter, and in larger numbers in the cooler main hall during summer.

${ }^{14}$ In rare emergency cases, the control room uses CCTV to guide patrols. All recordings are limited to seventy two hours, after which they overwrite. Footage can only be exported (and handed to police or prosecution) by a few pre-designated individuals, and upon the order of a prosecutor.
} 
Third, there are signs of the Hauptbahnhof dispositive becoming de-walled. Securitrans now patrols the site's outer perimeter (just as policemen always did), and SIP follows groups beyond the station premises. Cameras on (mainly local commuter) trains permit regional coverage of activities by the Transport Police (even if recordings can only be accessed ex post, for they must be physically retrieved). Most importantly, perhaps, Switzerland's participation in Schengen and Dublin granted access to European databases, which means that offenses registered in Zürich may now be brought to justice elsewhere (and vice versa). Yet, with the exception of these databases, expansions in the dispositive's operational reach do not seem radical.

However, if Deleuzian control scholarship overstates the new dispositives' reach, empirics suggest interesting internationalization processes in terms of its constitution. Thus, the police corps joined RAILPOL, a European network of rail police agents. Higher officers from Zürich attend German (Münster) or American (FBI) police academies for specialized training, and foreign policemen conduct internships at Hauptbahnhof. Architects develop transnational security standards for public transport infrastructures. Hauptbahnhof managers maintain an informal network with Berlin main station and Montparnasse, Paris, and, since 2003, the International Union of Railways, traditionally restricted to technical railway safety, has promoted broader security standards. With the notable exception of the European databases, then, the alleged globalization of security is difficult to substantiate-yet (and interesting not least considering Switzerland's skepticism towards European cooperation), significant transnationalization processes exist in terms of training and standardization.

Fourth, the reconfiguration of Hauptbahnhof security is indeed driven by technological innovation. Whether neoliberal politics and alarmist threat discourses are similarly important remains less evident. Switzerland is a pronouncedly marketfriendly polity-but the privatization of security, empirics show, is nonetheless limited. Also, fears of terrorism exist, are linked to international cases, and are sporadically renewed. Reactions to large-scale violence are prepared by first responders and civil protection, and counter-terrorism has become a primary task of the now combined Federal Intelligence Service. ${ }^{15}$ Most adaptations observed, however, are justified by small, urban problems such as littering, harassment, theft, drug abuse, fire, congested traffic, or evolving nightlife and shopping practices. These intensified with urbanization, individualization, the construction of high-speed lanes across Switzerland, new communication technologies, and the "24-hour society," as well as persistent global changes-not 9/11, but the opening of Eastern European borders, European integration, and protracted wars and unrest in the Balkans, Middle East, and North Africa.

Considering these insights, it appears reductive to identify a singular driver of the dispositive's development (for example, "neo-liberalism" or "terrorism" as catch-all causes). Complex multicausal mechanisms are at play, and while some are more influential than others, contemporary security remains heterogeneous and dependent on the actions of a plurality of actors. Similarly, resistance to contemporary control is observed throughout, not least as it is built into the policy field. Thus, executive practices are problematized by judges, data protection delegates, journalists, direct democracy instruments, and civil society groups such as ProBahn. Sometimes, they are also challenged from within the executive branch. SBB and the International Union of Railways managers, for instance, oppose the introduction of further security instruments into public transportation, the creation of passenger databases in particular. Cantonal and City Police lobby for human patrols instead of cameras, and architects and Transport Police explicitly prioritize, partly for budgetary reasons, low-tech measures over digital ones.

\footnotetext{
${ }^{15}$ The Hauptbahnhof knows of one case of "terrorism." In 1979 two bank robbers, later identified as members of the German Red Army Faction, shot a policeman and killed a bystander.
} 


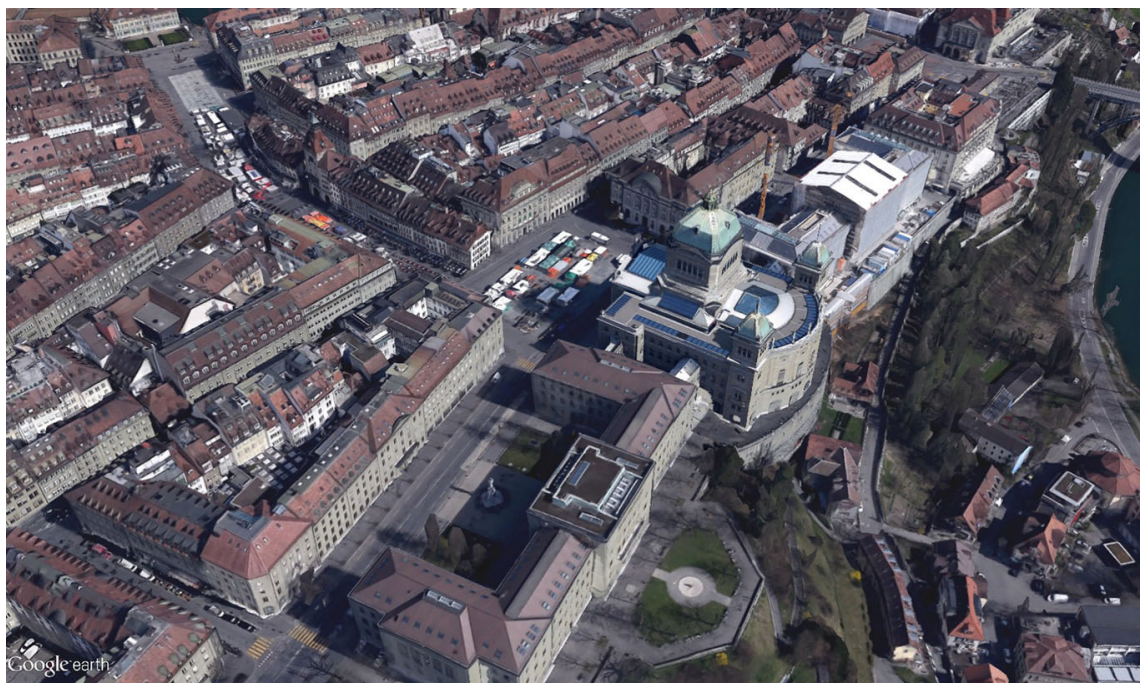

Figure 2. Bundesplatz Bern.

\section{Securing a Public Square}

Inquiry into the safeguarding of another type of urban milieu, a public square, also provides mixed findings and underscores the need for contextualized accounts of contemporary control. The Bundesplatz in Bern, Switzerland's most emblematic public space, is an instructive example. Carved out of the capital's old town in 1902, the square connects Bundeshaus (the federal parliament and government), the national bank, and the city center. Until its reconstruction in 2004, however, it merely served as a parking lot. Since then, its architectural reconstruction into a radically empty plane has made the Bundesplatz home to an array of societal functions. It serves as a rallying point for political mobilization efforts, whether by political parties or interest or diaspora groups; lends space to state visits, concerts, weekly crafts and annual cattle markets; and offers, with its animated and pedestrian-level fountains, a popular meeting place for locals and tourists alike (Bundesplatz 2016, cf. Figure 2).

With its distinct architectural, societal, and political characteristics, the Bundesplatz "works" differently than Zürich main station, and so does its securing. First, in terms of its evolving components, the security dispositive in Bern now connects more numerous actors than before-just as argued by Deleuzian control scholarship. First responders, architects, and private guards are regularly included in security planning today, and following a failed 2004 police lockdown of nearby nonconformist Reithalle, all public security authorities sit in the police's situation room. Yet, there was barely any shift to private security around the square. The Cantonal Police of Bern (into which the City Police was recently integrated) fulfils most security functions, from patrols to riot control and integrated emergency management. The Federal Intelligence Service monitors dangers to federal institutions and foreign embassies, and assists the police with their handling. The Federal Security Service guards access to the many federal buildings. Private guards are merely employed as aides during commercial events on the square or by some retailers nearby.

Contemporary Bundesplatz security draws on new high-tech tools. At federal buildings, sophisticated manlocks were installed following a deadly rampage at the cantonal parliament of Zug in 2001, and entrants must now identify and get their luggage screened. Local public transport agency Bernmobil installed cameras throughout its trams and buses, many of which pass through, or nearby, 
Bundesplatz. The Cantonal Police now employ a mobile camera during gatherings of concern (essentially manifestations and fan marches with violent potential) and consult the same national and (more recently) European databases as colleagues elsewhere in Switzerland.

Low-tech interventions are, however, just as important. The square's architectural rearrangement deliberately removed all hiding places. Alongside Bundeshaus, new subterranean anchors permit the rapid installation of sturdy fences, the lower Kleiner Strassenschutz or two-meter tall Bundessperre (both keep the building accessible to the public; the latter is used at events with over ten thousand participants). The police can now feed water cannons from the Bundeshaus and communicate with crowds through an upgraded on-site loudspeaker system (originally installed in the 1980s following noisy farmer protests). The square's lighting concept was improved, and the Bundeshaus was retrofitted with unbreakable windows. Bernmobil introduced wearproof material to its vehicles, and event organizers began using color bracelets to shepherd spectators. Market vendors still protect their tills with walls of empty fruit boxes.

The regulations centering on Bundesplatz resemble those in Zürich, for many security-related norms are federal. Additional cantonal and municipal laws forbid manifestations during parliament's four annual sessions and, since escalations in 2007, same-day counterdemonstrations. The municipality now obliges event organizers to deploy private guards. Such norms do not appear totalitarian, however, and the new federal instruments are not employed very often in Bern. Uses of stayaway orders, for instance, fluctuate between zero and forty per year around Bundesplatz and have not increased over time. Similarly, given the importance of standard operating procedures, the dispositive's speed of adaptation is not pronounced. Police commanders do redirect patrols to new places and formations during evolving events, and transport wagons speed up their redeployment. Such tactics are, however, nothing new and fairly conventional in themselves. What is more, the bulk of security preparations for state visits, manifestations and commercial events still occur weeks or months ahead of time.

Second, infringements of democratic ideals can be identified around the square but are patchy in everyday life. ${ }^{16}$ Video surveillance exists but is neither perfect nor permanent, and while the new square does not block any line of sight, nearby old town alleys offer plenty of hiding places. Also, agents do work with (often implicit) concepts of dangerous and unwarranted individuals and behavior, thus contributing to categorizations of problematic people. But, as in Zürich, their concepts are incongruent and do not create a neatly defined "other" in Bern (and they seem again more experiential than statistical in nature). The police, for instance, mainly focus on petty criminals and drug dealers, but the intelligence services focus on fascist, Marxist, religious, and ecological extremism. Bernmobil differentiates between tourists, (self-reliant) commuters, and (impatient) parliamentarians.

Control of public space, then, is nuanced in practice and more "public" and "low-tech" than in a site of mobility such as Zürich Hauptbahnhof, given also the different material configurations and social and political functions of these sites. Yet, the Bundesplatz dispositive features, and was recently enriched by, important channels for dialogue, public deliberation, and decision-making about security. Police officers became trained in community policing and now reach out over Twitter and Facebook. Personnel of the Cantonal Police, the Federal Security Service, and Bernmobil are regularly approached in person, called on their new hotlines, or sent emails with suggestions and (more often) complaints. Both Bernmobil and the interest group BernCity assess passengers' and costumers' reactions to current

\footnotetext{
${ }^{16}$ A different situation applies for state visits, when the Bundesplatz is in tight lockdown, with access roads blocked and windows facing the square closed. However, state visits are rare and not representative of everyday life or societal steering.
} 
security dispositives. As in Zürich, media outlets, municipal law-making, and executive accountability mechanisms are recurrently mobilized to question existing (in-) security concepts and practices.

Thirdly, with the European databases, the Bundesplatz security dispositive does show signs of de-walling. Other contributions to the expansion of control, however, are more ambivalent. The city's integration into the Cantonal Police and recent deepening of intercantonal police cooperation, for instance, empowered more immediate regional control, and cameras, fences, and architecture, too, intensified control practices in-place. However, whether they extended the dispositive's reachlet alone created an integrated global security system-is difficult to argue, for cantonal policing is nothing new, and the new tools' operations are essentially limited to their physical location. In the case of a public square, the operational globalization of control is thus difficult to substantiate. Yet, interesting debordering practices again appear in terms of the dispositive's self-constitution. In recent years, city and police officials began comparing their practices and performances (whether in administration, fining, or riot control) with national and international peers. The Cantonal Police introduced staff exchanges with Swiss and foreign corps and, since 2005, Bernmobil synchronizes security efforts through an informal network of urban public transport agencies.

Fourth, new technologies and concerns with terrorism contributed to the reconfiguration of Bundesplatz control, which also reflected its proximity to federal institutions and foreign embassies. Yet, technological change did not result solely in high-tech control, and fairly mundane problem rationales-concerns with theft, vandalism, drug abuse, or littering-motivated the great majority of the dispositive's recent changes. What is more, it was local and national incidents, such as a rampage in a cantonal legislature and escalation during demonstrations in Bern, which contributed to reconfigurations of the security deployment-not high-flying global narratives about 9/11 or Al-Qaeda. Also, resistance to security management around Bundesplatz is observed during the entire period of investigation. ${ }^{17}$ Thus, local media and parliamentarians regularly debate security practices. The Cantonal Police opposes certain embassies' insistence on extreme security measures. Bernmobil rejects, through its network of public transport security officials, the militarization (in appearance and weapons) of its staff and distances itself actively from police work. Some Bernmobil security officers even oppose their own agency's use of CCTV cameras. And finally, architects and city officials succeeded in their push for low-rise curbstones along the new Bundesplatz, thus privileging wheelchair access over anticar bollards.

\section{Securing a Site of Mass Commerce}

The securing of a commercial space provides a third and final empirical illustration of the evolution of control, its diversity, contradictions, and dependence on the material, social, and political configuration of a given urban milieu. St. Jakob Park (SJP) in Basel serves as a good example of this type of space. Built by Herzog \& de Meuron in 2001 and extended in 2007, SJP includes Switzerland's largest football stadium (38,512 seats, sixty thousand at concerts), a mall (fifty shops and restaurants), retirement home (108 apartments), and office tower. The UEFA Elite Stadium ${ }^{18}$ hosts games by FC Basel and the Swiss National Team (and tournament events such as the Swiss Cup Finals, the 2008 European Championship, or the

\footnotetext{
${ }^{17}$ They are also sustained by divisions of competencies between security actors. For example, the canton patrols the square, but the city prosecutor handles legal incidents occurring on it. By contrast, the sidewalk immediately surrounding Bundeshaus is federal territory, and federal prosecution is in charge of investigations inside the building.

${ }^{18}$ Or Category 4 stadium, the highest UEFA rank given to establishments including VIP lounges, serviced restaurants, TV studio, press and control rooms, underground and bus parking, emergency generators, and many more predefined features.
} 


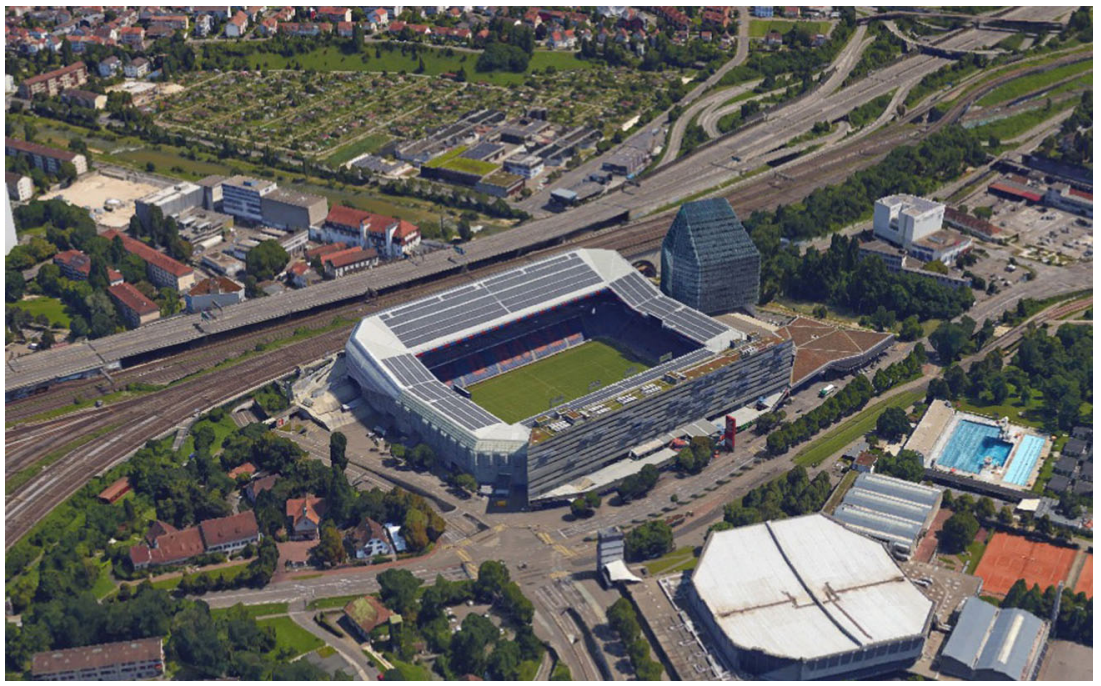

Figure 3. St. Jakob Park Basel.

2016 Europa League Final), concerts, and operas; its other components turn the park into an important regional shopping, meeting, and work place. The site features bus and tram stops and a train station and highway exit onto Europe's premier north-south corridor, the Gotthard route. It also sits on the border of two cantons and three municipalities and neighbors a public bath, hockey stadium, tennis hall, and multifloor nightclub (St. Jakob Park 2016; FC Basel 2016, cf. Figure 3).

First, both public and private actors recomposed the site's security dispositive in the last fifteen years. The Cantonal Police, ever present with plain-clothed, uniformed, or heavy patrols around St. Jakob Park, introduced and multiplied spotters in the early 2000s. Since 2001, Transport Police controls trains stopping at the park. Starting in 2005, a new social work agency, Fanarbeit Basel, liaises between authorities and fans, and, since 2010, a prosecutor is present at all games. ${ }^{19}$ Private stadium security shifted from voluntary to corporate and-unlike Bern's public square and Zürich's site of mobility-expanded significantly. Since 2001, site owner Basel United patrols the premises and controls its entrances, employs CCTV operators, works with guest clubs' security officers, and deploys between two hundred and 450 stewards during games. ${ }^{20}$

This expanding actor-landscape is paralleled by unprecedented, albeit incongruent, transfunctional coordination efforts. Since the European Championship, the police have convened a Permanent Working Group to prepare large-scale events with the neighboring canton's police, the Transport Police, SBB, transport agency Basler Verkehrsbetriebe, Fanarbeit, Basel United, and club security officers. ${ }^{21}$ Since the mid-2000s, local platform Basler Modell brings together city officials, FC Basel, fan delegates, and university sociologists and, since 2007, a nationwide Runder Tisch has connected the minister for sports, government agencies, and sports associations. In the background, the Swiss Football League (SFL) arbitrates a rapidly expanding portfolio of security incidents since 2003, and UEFA and FIFA (which created its

\footnotetext{
${ }^{19}$ The prosecutor registers testimonies from individuals not permanently in Basel, that is, spectators, auxiliary private guards, or policemen dispatched by other cantons.

${ }^{20}$ Commercial activities are handled by private companies of all sorts-caterers, retailers, and real-estate company Wincasa especially.

${ }^{21}$ During the European Championship, it also coordinated a deployment of policemen from German BadenWürttemberg.
} 
own Security Department in 2011) also regularly examine stadium security management.

Advanced technologies are prominent at St. Jakob. Since 2001, Basel United accesses seventy in-house cameras from an integrated control room. Transport Police controls six around the new train station, and Verkehrsbetriebe manages all those inside trams and busses. Wincasa, the company managing the nonstadium parts of SJP, maintains its own surveillance system, including cameras, sensors, and programmable door-locks. The police began using mobile cameras and installed fixed ones throughout the city during the European Championship. Basel United maintains a database of ticket holders, and SBB repeatedly attempts to introduce personalized tickets for away-fans. Policemen consult the same digital registries as colleagues in Bern and Zürich.

Mundane technologies are just as important. Building structures were redesigned to withstand potential destruction of walls, and fan sectors were physically compartmentalized to reduce mobility. New turnstiles permit individualized control of entrants, while oversized exit doors allow rapid evacuation. Nonflammable folding seats replaced standing places throughout to enhance mutual identification and reduce the risk of crushing. An elevated "event-platform" now surrounds the park, keeping visitors from the road. Since 2007, nets prevent falling and throwing of items onto an adjacent underpass. To deny hooligans "ammunition," Verkehrsbetriebe changed the filling of tram roadbeds from gravel to grass. The stadium speaker is now trained and used for crowd management. Pre-event controls were standardized, from shop delivery times to bomb inspection. The Transport Police returned to using dogs for patrols. The Cantonal Police now forms buffers, not cordons, when separating fans, and promotes de-escalation through novel withdrawal strategies. The mall's opening hours no longer interfere with stadium events. During "risk games," streets are now closed to traffic and light beer is served.

Existing control arguments seemingly fare better in the legal domain, for increased repression and normative targeting is indeed observed. Adding to norms already described, nationwide database HOOGAN was installed in 2007 to track violent sports fans. Of the (in 2016) 1,585 registered individuals, 690 are denied access to Swiss stadiums (football and hockey), 481 are sanctioned with stay-away orders, and nine are forbidden to attend international away-games (Fedpol 2016, SJP numbers not accessible). Police corps across Switzerland developed restrictive intercantonal regulations regarding sports events (so-called hooligan concordats). Basel United repeatedly tightened its house rules. The football associations prescribe ever more restrictive security norms to clubs (publishing detailed manuals on stadium design, crowd management, CCTV cameras, control rooms, etc.-see FIFA 2013) and impose hefty sanctions in case of noncompliance. In terms of flexibility, however, security practices barely support Deleuzian control scholars' claims about rapid adaptation. This is because security arrangements around SJP are highly standardized, whether by local actors, SFL, UEFA, or FIFA. Game-day security concepts, for example, are finalized along general lines ten days ahead of time; likewise, Verkehrsbetriebe must adjust their drivers' work schedules. When the park is rented out for concerts or operas, concepts must be preapproved three months in advance.

Second, there are also mixed results regarding the "totalitarian" character of SJP security. Cameras and databases multiplied, but self-removal from the dispositive remains possible, as camouflaged fan-groups regularly demonstrate. Security agents are "distanced" from visitors when in crowd-control gear but not otherwise. Basel Police spearheaded national efforts in community policing, and Basel United deploys hundreds of stewards for the very purpose of presenting interlocutors. Interestingly, in addition, the Permanent Working Group's planning is not so much based on statistics as on experiences and estimates, that is, rough numbers of expected visitors, the history of competitions between clubs, and the existence of parallel events nearby (such as the Swiss Indoors tennis tournament). 
Important subjectivation practices occur around SJP but are diverse even among security agents. Basel United differentiates between Kurve (dedicated juvenile fans), families, VIPs, and away-guests. Fanarbeit uses cultural categories of "game," "event-," and "consumption-oriented" visitors. FC Basel and Federal Police differentiate between (regular) A, (potentially violent) B, and (violent) C fans, but SFL abandoned this ABC scheme in favor of an even looser idea of "risk" and "non-risk" fans. Policemen distinguish Normalos, Ultras, away-fans, and hillbilliesNational Team supporters from the Hinterland, arguably the most unruly and problematic fans. FIFA knows sponsors and VIPs but no problem groups; also for fans there is no stable category at its (unpredictable) international tournaments. Concepts of dangerous persons, then, are numerous around SJP. Yet they are discontinuous, and their prevalence depends strongly on the precise type of event. What is more, various feedback and public codecision mechanisms also exist around St. Jakob. These are regularly seized by individuals, neighborhood associations, political parties and social work organizations, an empirical insight that differentiates the purported "totalitarian" nature of contemporary control.

Third, there are signs of security gaining wider reach around SJP. Thus, beyond European databases, police spotters and club security chiefs now cooperate intensively across Europe. This said, the internationalization of control seems more pronounced in constitutional than in operative terms, and this also applies to St. Jakob. Football associations and architects develop or prescribe increasingly restrictive and homogenous security standards (Herzog \& de Meuron, which also built stadiums in Munich, Cape Town, and Beijing, maintains its own Green Book compendium on best practices of stadium security). Leading up to the European Championship, the SJP security dispositive was assessed by an international team of experts, and, since then, Basel police regularly exchange best practices of stadium security with other European specialists. To harmonize standards, UEFA has, since 2012, offered Pan-European Football Police Training.

Fourth, technological progress and concerns with large-scale violence fed the described changes. But other factors-such as a new fan-culture (less political, but all the more loyal), the international successes of FC Basel, new trends towards multifunctional use of sports stadiums, memories of the 1985 Heysel stadium disaster and, especially, concerns about foreign visitors prior to the European Championship-were considerably more powerful. Articulation of such concerns rested on a diverse cast of interest groups and (municipal, cantonal, and federal) authorities and evolved unevenly over the last fifteen years, thus contextualizing Deleuzian scholars' focus on terrorism, capitalism, and other global narratives as supreme causes.

Scholarly calls for resistance, too, seem driven more by theoretical arguments than empirics, for resistance already exists in different forms. Thus, FIFA and SBB push for personalization of tickets, but SFL rejects this, and fans circumvent it by not buying away-fan transportation tickets (which come with personal identification). The Basel United database is ineffective since stadium passes circulate freely irrespective of their actual holders. Citizens of Basel rejected the intercantonal policing norms (the enhanced hooligan concordat) and, after the European Championship, local parliament forced de-installation of citywide cameras against the will of the police. Football associations seek interdiction of alcohol at the stadium, but fans respond by binge drinking outside, and Basel United too opposes said regulations (as it does police attempts at banning pyrotechnics), given its commercial interests in selling beverages and "emotions." The relocation of away-fans to a sector nearby the train station, arguably a particularly effective control measure, is successfully blocked by TV stations, who do not want this sometime unruly crowd within its cameras' range of operation. 


\section{Conclusion}

The control thesis contributes a powerful and stimulating analytical framework to the study of contemporary societal steering. Even if its popular presentation as an "update" of Foucaultian discipline may be misleading-with the exception of dedicated concerns with digitalism, privatization, and society's ability to influence security practices itself perhaps, the control society seems more of a morphological and spatial expansion of the disciplinary society than something entirely differentDeleuze's control thesis offers highly productive ideas with which to analyze the evolution of security management. In order to exploit this potential more systematically, however, it is imperative to advance the literature. The French philosopher's argument becomes more of a differentiating social science research framework, and less of a political manifesto, if it is decentered from all too intimate concerns with the new and the spectacular and employed in ways that also account for older, more enduring and mundane components of security.

The Swiss cases illustrate how such a move helps produce a considerably more refined understanding of security politics and practices. The three urban sites point to advanced specialization and cooperation among security agents but also the continuing predominance of state actors, given limited and uneven privatization, depending on place and the social functions to be controlled. They expose proliferation of digital technologies but also the persistence of old tools and the ever more sophisticated mobilization of low-tech, from architecture to communications and tactics, adjusted to space, site, and sometimes also time. They illustrate problematic encroachments of democratic ideals by refined security ensembles-but also disparate subjectivation processes, resistant practices outside and within security ensembles, and multiple old and novel public deliberation and codecision mechanisms. With this, the Swiss cases expose how a society is compartmentalized by normalizing ensembles but also how such practices are evolving and are less totalitarian than is argued, for control practices can be disparate, patchy, and contradictory. At the same time, the cases do lend weight to pervasive optimizations of security ensemblesprocesses that are more mundane and less spectacular than those suggested by the literature but no less concerning because of that.

A spatial and empirical heuristic is directly helpful to obtaining such differentiated insight, for it empowers refined genealogies of societal regularization across political and social systems (Selby 2007; Chenoweth and Clarke 2010). The Swiss cases already show how urban control differs across a given country and-when contrasted with the existing literature centering on British and American citiesseemingly also within the West. A comprehensive approach to control can accommodate this situation, for it recognizes security practices' dependence on varied political, technological, architectural, and societal characteristics. Eventually, this ability also allows the literature to venture beyond the West and to confront some more deeply ingrained disciplinary research tenets when so doing. Instead of concluding to global patterns of control from places where democratic mechanisms are a given, private property and free commerce the norm, advanced technologies readily available, and security concerns defined by occidental interests, it invites investigating temporal, intra-urban, nationwide, and global variations of security dispositives and their relations with local societal and political orders. How and why security ensembles are reassembled in regions such as Latin America or the Middle East (e.g., Jütersonke, Muggah and Rodgers 2008; Yacobi and Pullan 2014)—not just in Europe or the United States-and in cities such as Rio, Beirut, or Kigali (e.g., Amar 2008; Fawaz and Akar 2012; Parnell and Pieterse 2014) —not merely in London or New York City-turn into research questions that are to be answered by empirical investigation, not by a global scholarly narrative. More differentiated engagement with control thus not only helps generate richer and more refined understandings of evolving patterns of societal regulation, and more carefully substantiated 
normative ponderings of its relations with democratic ideals. It can also safeguard critical scholarship from uncritically projecting abroad universalisms of security politics- "critical truths" about operations and required responses to security politics that echo widely in some quarters but do not necessarily resonate well with practices on the ground.

\section{Acknowledgments}

Thanks to the referees and editors for their constructive comments on earlier versions of this article and to Ilyas Saliba for excellent research assistance.

\section{References}

Abrahamsen, Rita, and Michael Williams. 2010. Security Beyond the State: Private Security in International Politics. Cambridge: Cambridge University Press.

Abrahamsen, Rita, Don Hubert, and Michael Williams. 2009. "Guest Editors' Introduction.” Security Dialogue 40 (4-5): 363-72.

Adey, Peter. 2008. "Airports, Mobility and the Calculative Architecture of Affective Control." Geoforum 39 (1): 438-51.

Amar, Paul. 2008. "Operation Princess in Rio de Janeiro: Policing 'Sex Trafficking,' Strengthening Worker Citizenship, and the Urban Geopolitics of Security in Brazil.” Security Dialogue 40 (4-5): 51341.

Amicelle, Anthony, Claudia Aradau, and Julien Jeandesboz. 2015. "Questioning Security Devices: Performativity, Resistance, Politics.” Security Dialogue 46 (4): 293-306.

Aradau, Claudia, and Jef Huysmans. 2014. "Critical Methods in International Relations: The Politics of Techniques, Devices and Acts.” European Journal of International Relations 20 (3): 596-619.

BaIley, David. 2010. "The European Rescue, Recommodification, and/or Reterritorialisation of the (Becoming-Capitalist) State? Marx, Deleuze, Guattari, and the European Union." Journal of International Relations and Development 13 (4): 325-53.

Bennett, Jane. 2004. "The Force of Things: Steps Towards an Ecology of Matter." Political Theory. 32 (3): 347-72.

Bevir, Mark. 2010. "Rethinking Governmentality: Towards Genealogies of Governance." European Journal of Social Theory 13 (4): 423-41.

Bigo, Didier. 2001. "The Moebius Ribbon of Internal and External Security(ies)." In Identities, Borders, Orders: Rethinking International Relations Theory, edited by Mathias Albert, David Jacobson, and Yosef Lapid, 91-116. Minneapolis: University of Minnesota Press.

— 2005. "Global (In)Security: The Field of the Professionals of Unease Management and the Banopticon." In Translation, Philosophy and Colonial Difference, edited by Jon Salmon and Naoki Sakai, 109-57. Hongkong: University of Hongkong Press.

Blomley, Nicholas. 2007. "How to Turn a Beggar into a Bus Stop: Law, Traffic and the Function of Place." Urban Studies 44 (9): 1697-712.

Bonelli, Laurent, and Francesco Ragazzi. 2014. "Low-tech Security: Files, Notes, and Memos as Technologies of Anticipation.” Security Dialogue 45 (5): 476-93.

Brenner, Neil. 1999. "Globalisation as Reterritorialisation: The Re-scaling of Urban Governance in the European Union.” Urban Studies 36 (3): 431-51.

Bundesplatz, . 2016. Der Platz. Accessed April 12, 2016, http://www.bundesplatz.ch/bern/bundesplatz. html.

Bussolini, Jefrrey. 2010. "What Is a Dispositive?” Foucault Studies 10: 85-107.

CASTEls, RoBert. 1988. The Regulation of Madness: The Origins of Incarceration in France. Berkeley: University of California Press.

Chenoweth, Erica, and Susan Clarke. 2010. "All Terrorism is Local: Resources, Nested Institutions, and Governance for Urban Homeland Security in the American Federal System.” Political Research Quarterly 63 (3): 495-507.

Cheng, Jia-Lu. 2008. "On Control Societies: A Deleuzian Postscript." Paper Presented at the Institute of Ethnology, Academia Sinica, Taiwan, December 13- 14.

Coaffee, Jon, Paul O’Hare, and Marian Hawkesworth. 2009. "The Visibility of (In)security: The Aesthetics of Planning Urban Defences against Terrorism.” Security Dialogue 40 (4-5): 489-11.

Coleman, Mathew, and John Agnew. 2007. "The Problem with Empire." In Space, Knowledge and Power: Foucault and Geography, edited by Jeremy Crampton and Stuart Elden, 317-40. Aldershot: Ashgate. 
Coward, Martin. 2009. "Network-centric Violence, Critical Infrastructure and the Urbanization of Security.” Security Dialogue 40 (4-5): 399-418.

Delaney, David, and Helga Leitner. 1997. "The Political Construction of Scale.” Political Geography 16 (2): 93-97.

Deleuze, Gilles. 1992. "Postscript on the Societies of Control." October 59:3-7.

—. 2006. "What is a Dispositif?" In Two Regimes of Madness: Texts and Interviews 1975-1995, edited by David Lapoujade, 338-48. New York: Semiotext(e).

Deseris, Marco. 2011. "The General, the Watchman and the Engineer of Control: The Relationship between Cooperation, Communication, and Command in the Society of Control." Journal of Communication Inquiry 35 (4): 387-94.

Dillon, Michael, and Luis Lobo-Guerrero. 2008. "Biopolitics of Security in the 21st Century." Review of International Studies 37 (2): 265-92.

Fawaz, Mona, and Hiba Bou Akar. 2012. "Practicing (In)Security in the City." City E Society 24 (2): 105-9.

FC BASEL. 2016. Stadion Geschichte. Accessed July 9, 2016, https://www.fcb.ch/de-CH/Stadion/ Geschichte.

FEDPOL. 2016. Aktuelle Zahlen aus dem Informationssystem HOOGAN. Accessed June 16, 2016, https://www.fedpol.admin.ch/fedpol/de/home/sicherheit/hooliganismus/zahlen.html.

FIFA. 2013. Stadium Safety and Security Regulations. Zürich: FIFA.

Foucault, Michel. 1977. Discipline and Punish: The Birth of the Prison. London: Penguin.

—. 1978. "La société disciplinaire en crise." Dits Ev Ecrits III (231): 532-4.

. 1991. "Governmentality." In The Foucault Effect: Studies in Governmentality, edited by Graham Burchell, Colin Gordon, and Peter Miller, 87-104. Chicago: Chicago University Press.

—. 2004. Security, Territory, Population: Lectures at the Collège de France 1977-1978. New York: Picador.

Gammon, Earl, and Julian Reid. 2010. "Whither Deleuze and Guattari: A Critical Introduction.” Journal of International Relations and Development 13 (4): 323-4.

Goldstein, Daniel. 2010. "Toward a Critical Anthropology of Security." Current Anthropology 51 (4): 487517.

Goodsell, Charles. 2003. "The Concept of Public Space and its Democratic Manifestations." American Review of Public Administration 33 (4): 361-83.

Haggerty, Kevin, and Richard Ericson. 2000. "The Surveillant Assemblage.” British Journal of Sociology 51 (4): 605-22.

Hallsworth, Simon, and John Lea. 2011. "Reconstructing Leviathan: Emerging Contours of the Security State." Theoretical Criminology 15 (2): 141-57.

Hardt, Michael. 1998. "The Global Society of Control.” Discourse 20 (3): 139-52.

Hardt, Michael, and Antonio Negri. 2000. Empire. Cambridge: Harvard University Press.

Johnson, Heather. 2014. "Ethnographic Translations: Bringing Together Multi-sited Studies." Critical Studies on Security 2 (3): 362-5.

Joseph, Jonathan. 2010. "The Limits of Governmentality: Social Theory and the International." European Journal of International Relations 16 (2): 223-46.

Jütersonke, Oliver, Robert Muggah, and Dennis Rodgers. 2008. "Gangs, Urban Violence, and Security Interventions in Central America." Security Dialogue 40 (4-5): 373-97.

Koskela, Hille. 2000. "The Gaze without Eyes: Video-Surveillance and the Changing Nature of Urban Space." Progress in Human Geography 24 (2): 243-65.

—. 2003. "Cam Era-the Contemporary Urban Panopticon." Surveillance and Society 1 (3): 292-313.

LACY, MARk. 2008. "Designer Security: Control Society and MoMa's SAFE: Design Takes on Risk.” Security Dialogue 29 (2-3): 333-57.

Larkin, Brian. 2013. "The Politics and Poetics of Infrastructure." Annual Review of Anthropology 42: 327-43.

LefÈbvre, Henri. 1968. Le droit à la ville. Paris: Anthropos.

Lenco, Peter. 2014. "(Re-)Introducing Deleuze: New Readings of Deleuze in International Studies.” Millennium 41 (1): 124-44.

Loader, Ian, and Neil Walker. 2007. Civilizing Security. Cambridge: Cambridge University Press.

Lundborg, Tom. 2016. "The Virtualization of Security: Philosophies of Capture and Resistance in Baudrillard, Agamben and Deleuze." Security Dialogue 47 (3): 255-70.

Lundborg, Tom, and Nick Vaughan-Williams. 2015. "New Materialisms, Discourse Analysis, and International Relations: A Radical Intertextual Approach.” Review of International Studies 41 (1): 3-25.

Lyon, DAVID. 2001. Surveillance Society: Monitoring Everyday Life. Buckingham: Open University Press.

Massumi, Brian. 2002. A Shock to Thought: Expression after Deleuze and Guattari. London: Routledge.

Meiches, Benjamin. 2015. “A Political Ecology of the Camp.” Security Dialogue 46 (5): 476-92. 
Merlingen, Michael. 2006. "Foucault and World Politics: Promises and Challenges of Extending Governmentality Theory to the European and Beyond." Millennium 35 (1): 181-96.

Molloy, SEÁn. 2010. "From the Twenty Years' Crisis to Theory of International Politics: A Rhizomatic Reading of Realism." Journal of International Relations and Development 13 (4): 378-404.

Muller, Benjamin. 2008. "Securing the Political Imagination: Popular Culture, the Security Dispositif and the Biometric State.” Security Dialogue 39 (2-3): 199-220.

Muller, Benjamin, Thomas N. Cooke, Miguel de Larrinaga, Philippe M. Frowd, Deljana Iossifova, Daniela Johannes, Can E. Mutlu, and Adam Nowek. 2016. "Ferocious Architecture: Sovereign Spaces/Places by Design.” International Political Sociology 10 (1): 75-96.

Munro, Ian. 2002. "Empire: The Coming of the Control Society." Ephemera 2 (2): 175-85.

Newman, Saul. 2009. "Politics in the Age of Control." In Deleuze and New Technology, edited by Mark Poster and David Savat, 104-22. Edinburgh: Edinburgh University Press.

Parnell, Susan, and Edgar Pieterse. 2014. Africa's Urban Revolution. Chicago: University of Chicago Press.

Poster, Mark. 2009. “Afterword.” In Deleuze and New Technology, edited by Mark Poster and David Savat, 258-62. Edinburgh: Edinburgh University Press.

Reid, Julian. 2014. "Climate, Migration, and Sex: The Biopolitics of Climate-Induced Migration." Critical Studies on Security 2 (2): 196-209.

Rose, Nikolas. 1999. Powers of Freedom: Reframing Political Thought. Cambridge: Cambridge University Press.

- 2000. "Government and Control." British Journal of Criminology 40 (2): 321-39.

Sвв. 2016. Welcome to ShopVille-Zurich Main Station. Accessed April 12, 2016, http://www.sbb.ch/en/ station-services/am-bahnhof/railway-stations/shopville-zuerich-main-station.html.

SAlter, Mark. 2007. "Governmentalities of an Airport: Heterotopia and Confession." International Political Sociology 1 (1): 49-66.

SELby, 2007. "Engaging Foucault: Discourse, Liberal Governance and the Limits of Foucauldian IR." International Relations 21 (3): 324-45.

Sт. РАRк, Јаков. 2016. St. Jakob Park-Willkommen. Accessed July 9, 2016, http://www.st-jakobpark.com/home.html.

The Invisible Committee. 2009. The Coming Insurrection. New York: Semiotext(e).

Tiessen, Matthew. 2011. "Being Watched Watching Watchers Watch: Determining the Digitized Future while Profitably Modulating Pre-emption.” Surveillance E Society 9 (1/2): 167-84.

Valverde, Mariana. 2010. "Questions of Security: A Framework for Research.” Theoretical Criminology 15 (1): 3-22.

ViriLIO, PAul. 2012. The Administration of Fear. New York: Semiotext(e).

VLCEK, William. 2010. "Alongside Global Political Economy—a Rhizome of Informal Finance." Journal of International Relations and Development 13 (4): 429-51.

Wichum, Ricky. 2013. "Security as Dispositif: Michel Foucault in the Field of Security." Foucault Studies 15: 164-71.

Yacobi, Haim, and Wendy Pullan. 2014. "The Geopolitics of Neighbourhood: Jerusalem's Colonial Space Revisited." Geopolitics 19 (3: 514-39.

Zedner, Lucia. 2003. “Too Much Security?” International Journal of the Sociology of Law 31 (3): 155-84.

—. 2009. Security. London: Routledge. 